Syntax Literate: Jurnal Ilmiah Indonesia p-ISSN: 2541-0849

e-ISSN : 2548-1398

Vol. 6, No. 10, Oktober 2021

\title{
ANALISIS PERLINDUNGAN HUKUM KONSUMEN PRODUK KECANTIKAN YANG DIPASARKAN SECARA ONLINE
}

\section{Yani Kamasturyani}

Sekolah Tinggi Ilmu Kesehatan (STIKES) Mahardika Cirebon, Jawa Barat, Indonesia

Email: bundayani.mahardika@gmail.com

\begin{abstract}
Abstrak
Penelitian ini bertujuan untuk menganalisis perlindungan hukum bagi konsumen produk kecantikan yang dipasarkan secara online serta mengetahui upaya yang dilakukan oleh Balai Besar Pengawasan Obat dan Makanan (BBPOM) dalam melindungi konsumen produk kecantikan yang diperdagangkan secara online. Penelitian kualitatif ini menggunakan teknik penelitian kepustakaan (library research) dan penelitian lapangan (field research). Penelitian lapangan dilakukan secara yuridis empiris, Selain metode yuridis empiris, digunakan juga metode yuridis normatif dengan bahan hukum sekunder. Populasi terdiri dari para mahasiswi di lingkungan Sekolah Tinggi Ilmu Kesehatan Mahardika Cirebon, Jawa Barat, Indonesia. Hasil penelitian menunjukkan Jenis Produk Produk Kecantikan yang Sering dikonsumsi masyarakat dan di beli secara online terbanyak adalah pemutih kulit wajah sebanyak $70 \%$, dan secara umum belum semua orang memahami tentang perlindungan hukum bagi konsumen akibat mengonsumsi obatobat kecantikan yang mengakibatkan konsumen menderita kerugian. Para pelaku perdagangan online dapat diberikan sanksi administrasi (teguran sampai pembekuan izin edar), sanksi keperdataan (ganti rugi dalam hal perbuatan melawan hukum dan wanprestasi), dan sanksi pidana (hukuman fisik kurungan penjara dalam waktu tertentu).
\end{abstract}

Kata Kunci: perlindungan hukum konsumen; produk kecantikan; perdagangan online

\section{Abstract}

The study aims to analyze legal protections for consumers of beauty products marketed online as well as to find out the efforts made by the Food and Drug Control Center (BBPOM) in protecting consumers of beauty products traded online. This qualitative research uses library research techniques and field research. Field research is conducted in empirical juridical, in addition to empirical juridical methods, normative juridical methods are also used with secondary legal materials. The population consists of students in the Mahardika Cirebon College of Health Sciences, West Java, Indonesia. The results showed that the type of beauty products that are often consumed by the public and purchased online the most is facial skin whitening as much as 70\%, and in general not everyone understands about legal protections for consumers due to taking beauty drugs that result in consumers suffering losses. Online traffickers can be given administrative sanctions (reprimand until freezing of licenses), civil sanctions

$\begin{array}{ll}\text { How to cite: } & \text { Kamasturyani. Y (2021) Analisis Perlindungan Hukum Konsumen Produk Kecantikan yang Dipasarkan } \\ & \text { Secara Online. Syntax Literate: Jurnal Ilmiah Indonesia, 6(10). http://dx.doi.org/10.36418/ Syntax- } \\ & \text { Literate.v6i10.4375 } \\ \text { E-ISSN: } & \text { 2548-1398 } \\ \text { Published by: } & \text { Ridwan Institute }\end{array}$


(compensation in the case of unlawful acts and default), and criminal sanctions (corporal punishment of imprisonment within a certain time).

Keywords: protection of consumerlaw; beauty products; online trading

Received: 2021-09-20; Accepted: 2021-10-05; Published: 2021-10-20

\section{Pendahuluan}

Perlindungan hukum konsumen produk kecantikan yang dipasarkan secara online menjadi hal yang harus diperhatikan. Konsumen produk kecantikan, dalam hal ini konsumen produk kecantikan untuk tujuan mempercantik diri, pada dasarnya menginginkan kenyamanan, keamanan, dan keselamatan terhadap produk kecantikan yang mereka konsumsi. Namun, karena keterbatasan yang mereka miliki sebagai akibat dari tingkat pendidikan yang rendah, tingkat literasi yang rendah, dan pengaruh promosi, konsumen bisa terjebak dan atau terjerumus membeli untuk selanjutnya mengonsumsi obat-obat produk kecantikan tertentu baik melalui toko obat kecantikan yang umum atau belanja online yang di kemudian hari ternyata mendatangkan risiko berbahaya. Konsumen yang termasuk kategori ini jelas perlu dilindungi (Amelia \& Rismawati, 2018).

Kini, banyak beredar jenis produk kecantikan yang terdiri dari obat pemutih wajah, obat jerawat, obat pelangsing tubuh, dll., merupakan representasi dari artifak upaya seseorang untuk mengubah dirinya menjadi cantik atau tergolong cantik. (Hall, 1997) menyatakan bahwa representasi adalah penghubung antara konsep dan bahasa yang membuat seseorang mampu mengacu pada dunia nyata maupun hayalan.kondisi seperti ini dimanfaatkan oleh para pengusaha kecantikan yang hanya mementingkan segi keuntungan, sehingga pada akhirnya konsumen dirugikan (Fiske, 2004).

Menurut Pasal 1 angka 4 Undang-Undang No. 36 Tahun 2009 tentang Kesehatan (selanjutnya disingkat UU Kesehatan), kosmetik termasuk ke dalam jenis sediaan farmasi berkaitan dengan obat-obatan, Obat (atau yang sering disebut sebagai obat modern) adalah suatu bahan atau paduan bahan-bahan yang dimaksudkan untuk digunakan dalam menetapkan diagnosis, mencegah, mengurangkan, menghilangkan, menyembuhkan penyakit atau gejala penyakit, luka atau kelainan badaniah dan rohaniah pada manusia atau hewan dan untuk memperelok atau memperindah badan atau bagian badan manusia.

Hingga kini setidaknya terdapat dua kebijakan pemerintah Indonesia yang secara operasional melindungi para konsumen produk-produk kecantikan (Hamid \& SH, 2017). Pertama, Undang-Undang Nomor 8 tahun 1999 tentang Perlindungan Konsumen. Kedua, Peraturan Kepala Badan Pengawasan Obat dan Makanan (BPOM) Republik Indonesia Nomor 12 Tahun 2015 tentang Pengawasan Pemasukan Obat dan Makanan ke dalam Wilayah Indonesia. Hasil penelitian (Masputra, Setiyono, \& Irawati, 2020) penggunaan obat ataupun krim yang diberikan oleh dokter klinik kecantikan tidak lepas dari supervisi yang berasal dari BPOM. Hal ini relatif akan mengurangi risiko 
dampak negatif obat kecantikan sebab dokter kecantikan diasumsikan telah memahami betul jenis obat kecantikan serta dosisnya.

Dalam upaya melindungi konsumen produk maka hukum yang sesuai adalah hukum perlindungan konsumen. Kepala Badan Pengawasan Obat dan Makanan Republik Indonesia Nomor 12 Tahun 2015 seperti telah disebutkan di muka. Obat yang masuk dan diedarkan ke dalam wilayah Indonesia (termasuk obat kecantikan) harus memiliki izin edar dari BPOM (Pasal 3, ayat 1) (Rahmayani, 2018). Izin edar berupa notifikasi dari BPOM dinilai menjamin bahwa obat yang diperdagangkan aman untuk dikonsumsi.

Penelitian ini bertujuan untuk (1) mengetahui jenis produk kecantikan yang dikonsumsi masyarakat dan didapatkan melalui online; (2) menganalisis upaya hukum apa saja yang dapat dilakukan oleh konsumen terhadap produk produk kecantikan yang diperdagangkan secara online dan merugikan, dan (3) mengetahui upaya yang dilakukan oleh Balai Besar Pengawasan Obat dan Makanan (BBPOM) dalam melindungi konsumen produk kecantikan yang diperdagangkan secara online.

\section{Metode Penelitian}

Penelitian kualitatif ini menggunakan teknik penelitian kepustakaan (library research) (Rahayu, SH, \& Ke, 2020) dan penelitian lapangan (field research). Penelitian lapangan dilakukan secara yuridis empiris, yaitu metode penelitian untuk mendapatkan data primer dari data di lapangan tentang peraturan-peraturan hukum perdagangan obat-obat kecantikan secara online dikaitkan dengan data perilaku konsumen obat-obat kecantikan. Selain metode yuridis empiris, digunakan juga metode yuridis normatif dengan bahan hukum sekunder (Gustiani, 2019). Populasi terdiri dari para mahasiswi di lingkungan sekolah tinggi kesehatan Mahardika Cirebon, Jawa Barat, Indonesia.

Sampel diambil dengan purposive sampling atau judgement sampling. Sampel penelitian ini merupakan para mahasiswi yang memiliki kriteria khusus yaitu pernah membeli produk kecantikan secara online sehingga dianggap memiliki pengalaman sebagai konsumen produk kecantikan online.

Teknik analisis data menggunakan deskriptif analitik (Nazir, 1988) dengan unit analisis terdiri dari: jenis obat-obat kecantikan yang dikonsumsi dengan cara membeli secara online, perlindungan hukum yang diterima konsumen, upaya hukum yang dilakukan konsumen, dan upaya BBPOM untuk melindungi konsumen produk produk kecantikan.

\section{Hasil dan Pembahasan}

Data hasil wawancara dan jawaban atas pertanyaan tentang jenis-jenis obat kecantikan yang dikonsumsi dengan cara membeli secara online terkumpul data yang disajikan alam Tabel 2 berikut ini. 
Tabel 1

Jenis Produk Produk Kecantikan yang Dikonsumsi (Menurut Jumlah Pemakai)

\begin{tabular}{clcc}
\hline No. & Jenis Produk Kecantikan & Jumlah Pemakai & $\%$ \\
\hline 1. & Obat Pemutih Kulit Wajah & 45 & $45 \%$ \\
\hline 2. & Obat Penyembuh Jerawat & 20 & $20 \%$ \\
\hline 4. & $\begin{array}{l}\text { Obat Pewarna/Penghitam } \\
\text { Rambut }\end{array}$ & 10 & $10 \%$ \\
\hline 6. & $\begin{array}{l}\text { Obat Penghalus/ Pelembut } \\
\text { Kulit }\end{array}$ & 25 & $25 \%$ \\
\hline & Jumlah & 100 orang & $100 \%$
\end{tabular}

Sumber: Data Hasil Wawancara dan Angket (Diolah untuk Jurnal)

Analisis terhadap data jawaban dari responden tersebut dapat dirinci berikut ini. Temuan penelitian pertama, jenis-jenis obat produk kecantikan yang sering dibeli secara online di kalangan mahasiswi STIKes Mahardika Cirebon terdiri dari: obat pemutih kulit wajah, obat jerawat, dan obat pelembut kulit.

Pada umumnya obat-obat produk kecantikan yang terbanyak beredar secara online dan dikonsumsi oleh konsumen diperuntukkan bagi perbaikan kondisi wajah. Hal ini senada dengan pernyataan (Stufflebeam \& Shinkfield, 2012) dan (Vidyarini, 2007) yang menyebutkan bahwa wajah merupakan bagian fisik manusia yang unik, lunak, dan bersifat publik, serta menjadi dasar persepsi tentang arti kecantikan atau ketidakcantikan seseorang.

Obat pemutih dan pencerah wajah merupakan obat kecantikan yang paling banyak dikonsumsi secara online oleh responden di kalangan mahasiswi STIKes Mahardika. Hal ini sesuai dengan hasil penelitian (Vidyarini, 2007) yang menyebutkan bahwa kebanyakan produk kecantikan yang dipasarkan di Indonesia adalah produk yang bisa menjadikan kulit menjadi lebih terang. Menurut temuannya, label whitening (memutihkan) dan brightening (mencerahkan) adalah label yang terpampang di hampir semua produk perawatan kulit dan wajah.

Setelah obat-obat kecantikan untuk wajah, obat-obat produk kecantikan yang banyak diperdagangkan secara online adalah obat-obat yang diperuntukkan bagi kelembutan kulit. Urutan ketiga terbanyak dikonsumsi adalah obat-obat kecantikan penyembuh jerawat.

Jenis-jenis obat produk kecantikan tersebut banyak diperdagangkan secara online sebab sejak dulu, produk kecantikan dibuat sesuai dengan persepsi masyarakat tentang kecantikan itu sendiri. Kecantikan dimaknai berbeda oleh berbagai orang di belahan dunia yang berbeda. Oleh karena itu dalam perdagangan online jenis produk produk kecantikan berbeda-beda di setiap belahan dunia. Temuan berikutnya menunjukkan bahwa responden pada umumnya menyatakan kecantikan direpresentasikan dalam wujud model perempuan yang tinggi dan kurus/langsing, berkulit putih, berambut hitam lurus, dan berwajah Indo.

Bentuk iklan produk produk kecantikan yang disebarluaskan di berbagai media umumnya memiliki ciri utama yaitu menggunakan gambar atau sosok perempuan cantik berkulit putih dan tinggi semampai. Temuan ini memperkuat hasil penelitian (Dayanti, 
2006) yang menemukan bahwa produk-produk yang ditujukan untuk perempuan umumnya menggunakan model h yang secara fisik sempurna.

Kondisi tersebut sesuai pula dengan hasil penelitian (Vidyarini, 2007) yang menyimpulkan bahwa kecantikan yang ditampilkan dalam iklan adalah kecantikan ideal yang ditampilkan di media massa pada umumnya. Berdasarkan penelitiannya, kecantikan ideal adalah pada wajah yang memilki kualitas kulit putih, halus, dan bersih.

Temuan penelitian ketiga, masih banyak konsumen produk-produk kecantikan yang diperdangkan secara online belum terlindungi sepenuhnya, khususnya adanya kerugian yang disebabkan oleh akibat buruk dari obat kecantikan tersebut. Hal ini terjadi karena produsen yang menawarkan produk produk kecantikan tersebut tidak menyantumkan informasi tentang produk dimaksud secara benar dan jelas.

Hal ini bertentangan dengan keharusan bagi produsen (termasuk produsen produk produk kecantikan) untuk menyantumkan hal-hal terkait produknya. Menurut (Sukandar, Andrajati, Adnyana, Setiadi, \& Kusnandar, 2009) produsen produk obat ketika obat tersebut diperdagangkan harus menyantumkan: nama dagang, nama generik, bentuk sediaan, komposisi, indikasi, kontraindikasi, efek samping, interaksi obat, cara kerja obat, aturan pakai, peringatan, nomor batch/lot, nomor registrasi, nama dan alamat industri farmasi, dan tanggal kadaluwarsa.

Informasi tentang produk kecantikan yang diperdagangkan secara online penting diberikan sebab selain menyebabkan dampak positif, obat juga menyebabkan dampak negatif. Ketika cukup banyak obat kecantikan yang diperdagangkan secara online ternyata tidak mendapat izin dari BPOM dan informasi lain tentang obat tersebut tidak jelas, maka perlindungan terhadap konsumen terancam.

Meskipun efek negatifnya berbahaya, namun karena serbuan iklan obat kecantikan yang mudah masuk secara online ke HP konsumen, mudahnya transaksi online, menyebabkan konsumen obat kecantikan yang berbahaya ini tetap banyak jumlahnya. Di sisi lain, konsumen yang memperoleh produk kecantikan dari dokter kecantikan pun bisa saja dirugikan jika ternyata obat yang diperolehnya melalui dokter kecantikan juga belum terdaftar di BPOM.

Jika sudah seperti itu kondisinya, maka perlindungan konsumen akan pentingnya kesehatan mereka menjadi lemah. Padahal kesehatan sudah menjadi kebutuhan yang tidak bisa dipisahkan dari kehidupan manusia yang stratanya sama dengan kebutuhan akan sandang, pangan, dan papan. Menurut WHO kesehatan merupakan keadaan sejahtera dari fisik, mental, spiritual dan sosial yang memungkinkan setiap orang untuk hidup produktif baik secara sosial dan ekonomis dan untuk menjamin kualitas kesehatan tersebut diperlukan hukum kesehatan.

WHO dalam Effective Drug Regulation (A Multicountry Study) tahun 2002 dinyatakan bahwa kegiatan pengawasan bertujuan untuk menjamin keamanan, khasiat dan mutu obat yang tersedia untuk masyarakat, pengawasan ini perlu diatur dalam suatu legislasi di bidang obat yang mengatur secara komprehensif persyaratan terkait produk dan seluruh rangkaian kegiatan yang harus dilakukan sebelum dan sesudah produk 
diedarkan, termasuk di dalamnya seluruh aspek kegiatan terkait produksi, importasi, peredaran termasuk penyaluran, dan kegiatan promosi produk.

Pentingnya perlindungan hukum terhadap konsumen obat kecantikan yang diberikan oleh dokter kecantikan pun diperlukan, sebab dokter juga manusia yang memiliki kekurangan dan lupa (Mariam, 2017). Ketika lupa telah memberikan obat kepada pasien padahal obat tersebut belum terdaftar di BPOM. Misalnya seperti temua penelitian (Masputra et al., 2020) atas kasus Dr. Trifena yang memberikan obat kecantikan kepada pasien, padahal obat tersebut belum terdaftar di BPOM. Dr. Trifena dinyatakan secara legal bersalah oleh pengadilan dengan Putusan Nomor 2008K/Pid.Sus/2016.

Pentingnya perlindungan hukum bagi pasien akibat mengonsumsi produk kecantikan yang diperoleh dari tenaga medis juga sesuai dengan hasil penelitian (Poli, 2018) yang menyebutkan tanggung jawab dan sanksi yang diterapkan bagi tenaga kesehatan ataupun apoteker yang melakukan kesalahan atau kelalaian dalam memberikan obat sehingga mengakibatkan pasien/konsumen menderita kerugian dapat diberikan sanksi administrasi (teguran sampai pembekuan izin tenaga kesehatan), sanksi keperdataan (ganti rugi dalam hal perbuatan melawan hukum dan wanprestasi), dan sanksi pidana (hukuman fisik kurungan penjara dalam waktu tertentu).

Temuan penelitian keempat, terdapat beberapa upaya hukum yang dapat dilakukan oleh konsumen terhadap produk kecantikan yang diperdagangkan secara online, meliputi: (a) 5\% konsumen melaporkan kerugian kepada pemerintah untuk mendapatkan ganti rugi, (b) $41 \%$ konsumen tidak melaporkan kerugian kepada siapapun, (c) 17\% konsumen berhenti mengonsumsi obat kecantikan yang merugikan tersebut, (d) $37 \%$ konsumen tetap mengonsumsi obat kecantikan dengan cara mengganti obat kencantikan yang merugikan tersebut dengan obat sejenis namun berbeda merek.

Besarnya persentase konsumen yang tidak melaporkan kerugiannya menunjukkan adanya ketidaksadaran atau kekurangsadaran hukum di kalangan konsumen. Kondisi ini sekaligus menunjukkan diperlukannya peranan yang lebih besar dari pemerintah untuk melakukan dua hal. Pertama, meningkatkan kesadaran hukum pada kalangan konsumen produk kecantikan yang berbelanja secara online. Kedua, lebih intensif dan tegas mengawasi perdagangan produk kecantikan secara online. Ketiga, menegakkan proses hukum di pengadilan terhadap berkas aduan kasus obat kecantikan yang masuk.

Upaya kedua yang dimaksud memang sudah pernah dilakukan, misalnya pada kasus aduan pasien terhadap Dr. Trifena binti Yusuf seperti telah dikemukakan di atas. Menurut hasil penelitian (Masputra et al., 2020) Dr. Trifena diputus bersalah dalam Putusan Nomor 2008 K/Pid.Sus/2016 bukan karena meracik obat, namun karena menggunakan produk yang belum terdaftar di BPOM.

Temuan penelitian kelima, upaya Balai Besar Pengawasan Obat dan Makanan (BBPOM) dalam melindungi konsumen produk kecantikan yang diperdagangkan secara online adalah telah melakukan upaya perlindungan konsumen. 
Secara terjadwal BPOM sudah menyosialisasikan berbagai peraturan yang berlaku terkait obat dan makanan yang boleh dan tidak boleh diedarkan (diperdagangkan) baik secara konvensional maupun secara online. Implikasinya penggunaan semua produk terapetik, narkotika, psikotropika, zat adiktif, obat tradisional, kosmetik (baik obat atau krim) kecantikan (yang diberikan oleh dokter atau membeli secara online) harus memenuhi aturan yaitu memiliki izin edar dari BPOM.

Jika ada yang mengedarkan obat-obat kecantikan yang tidak terdaftar di BPOM, memperdagangkan, bahkan memberikan resep sekalipun (tindakan ini dilakukan dokter kecantikan), dapat dikenai sanksi pidana.

\section{Kesimpulan}

Berdasarkan hasil analisis dan pembahasan di atas diperoleh simpulan berikut ini. Pertama, Obat pemutih dan pencerah wajah merupakan obat kecantikan yang paling banyak dikonsumsi dan di beli secara online oleh responden di STIKes Mahardika Cirebon. Kedua masih banyak konsumen produk produk kecantikan yang dipasarkan secara online belum terlindungi sepenuhnya, khususnya adanya kerugian yang disebabkan oleh akibat buruk dari obat kecantikan tersebut. Ketiga Besarnya persentase konsumen yang tidak melaporkan kerugiannya menunjukkan adanya ketidaksadaran atau kekurangsadaran hukum di kalangan konsumen. Keempat BPOM telah mengeluarkan syarat peredaran obat harus memiliki izin BPOM, tetapi para pelaku perdagangan online masih banyak yang kurang peduli atas keselamatan konsumen. 


\section{BIBLIOGRAFI}

Amelia, Natasha, \& Rismawati, Rismawati. (2018). Perlindungan Konsumen Terhadap Produk Kecantikan Yang Diperdagangkan Secara Online Terkait Dengan Obat Pelangsing. Jurnal Ilmiah Mahasiswa Bidang Hukum Keperdataan, 2(3), 629-638. Google Scholar

Dayanti, Liestianingsih Dwi. (2006). Potret Kekerasan Gender dalam Sinetron Komedi. di Televisi. Jurnal Masyarakat, Kebudayaan Dan Politik, 19(3). Google Scholar

Fiske, John. (2004). Culture and communication studies. Jalasutra, Yogyakarta. Google Scholar

Gustiani, Sri. (2019). Research And Development (R\&D) Method As A Model Design In Educational Research And Its Alternatives. Holistics, 11(2). Google Scholar

Hall, Stuart. (1997). Representation: Cultural representations and signifying practices (Vol. 2). Sage. Google Scholar

Hamid, Abd Haris, \& SH, M. H. (2017). Hukum Perlindungan Konsumen Indonesia (Vol. 1). Sah Media. Google Scholar

Mariam, Mariam. (2017). Perlindungan Hukum Terhadap Konsumen Atas Peredaran Produk Kecantikan Yang Tidak Memiliki Izin Edar (Studi di Balai Besar Pengawas Obat dan Makanan Mataram. Universitas Mataram. Google Scholar

Masputra, M. Hendra Cordova, Setiyono, Joko, \& Irawati, Irawati. (2020). Keadilan Terhadap Dokter Pada Kasus Penggunaan Obat Yang Belum Terdaftar Di Bpom Republik Indonesia. Jurnal Pembangunan Hukum Indonesia, 2(1), 102-116. Google Scholar

Nazir, Moh. (1988). MetodePenelitian. Jakarta: Ghalia Indonesia. Google Scholar

Poli, Mirza N. R. (2018). Kesalahan Pemberian Obat Dalam Perspektif Undang-Undang Nomor 8 Tahun 1999 Tentang Perlindungan Konsumen. Lex Privatum, 6(4). Google Scholar

Rahayu, Derita Prapti, SH, M. H., \& Ke, Sesi. (2020). Metode Penelitian Hukum. Yogyakarta: Thafa Media. Google Scholar

Rahmayani, Nuzul. (2018). Tinjauan Hukum Perlindungan Konsumen Terkait Pengawasan Perusahaan Berbasis Financial Technology di Indonesia. Pagaruyuang Law Journal, 2(1), 24-41. Google Scholar

Stufflebeam, Daniel L., \& Shinkfield, Anthony J. (2012). Systematic evaluation: A selfinstructional guide to theory and practice (Vol. 8). Springer Science \& Business Media. Google Scholar 
Sukandar, Elin Yulinah, Andrajati, R. Sigit, Adnyana, J. I., Setiadi, I. K., \& Kusnandar, A. P. (2009). ISO: Farmakoterapi, PT. ISFI Penerbit Jakarta. Google Scholar

Vidyarini, Titi Nur. (2007). Representasi kecantikan dalam iklan kosmetik The Face Shop. Scriptura, 1(2). Google Scholar

\section{Copyright holder:}

Yani Kamasturyani (2021)

First publication right:

Syntax Literate: Jurnal Ilmiah Indonesia

This article is licensed under:

(c) (i) (?) 